\title{
Increased Expression of the Interleukin 1 Receptor on Blood Neutrophils of Humans with the Sepsis Syndrome
}

Mary Beth Fasano, Sue Cousart, Sara Neal, and Charles E. McCall

Section on Infectious Diseases, Department of Medicine, Wake Forest University Medical Center, Winston-Salem, North Carolina 27157

\begin{abstract}
Because of the potential importance of interleukin 1 (IL-1) in modulating inflammation and the observations that human blood neutrophils (PMN) express IL-1 receptors (IL-1R) and synthesize IL-1 $\alpha$ and IL-1 $\beta$, we studied the IL-1R on blood PMN from a group of patients with the sepsis syndrome. We report a marked enhancement in the sites per cell of IL-1R expressed on sepsis-PMN of 25 consecutively studied patients compared to 20 controls (patient mean $=9,329 \pm 2,212 \mathrm{SE}$; control mean $=716 \pm 42 \mathrm{SE}$, respectively). There was no demonstrable difference in the $K_{d}$ of IL-1R on sepsis-PMN $(\sim 1 \mathrm{nM})$ as determined by saturation curves of ${ }^{125} \mathrm{I}-\mathrm{IL}-1 \alpha$ binding and the IL-1R on sepsis-PMN had an apparent $M_{\mathrm{r}} \sim 68,000$, a value like that of normal PMN. Cytofluorographic analysis indicated that the sepsis-PMN phenotype is a single homogeneous population with respect to IL-1R expression. In contrast, expression of the membrane complement receptor CR3 is not increased on sepsis-PMN. Similar increases in expression of $I L-1 R$ were not observed in various other inflammatory processes, including acute disseminated inflammation and organ failure not caused by infection, acute infection without organ failure, and immunopathologies such as active systemic lupus erythematosus and rheumatoid arthritis. Enhanced expression of IL-1R was not related simply to the state of myeloid stimulation. Increased expression of IL-1R on normal PMN was induced in vitro by incubating cells with recombinant human granulocytemacrophage/colony-stimulating factor for $18 \mathrm{~h}$ and this response was inhibited by cycloheximide, suggesting the possibility that de novo synthesis of IL-1R might occur in PMN during the sepsis syndrome. (J. Clin. Invest. 1991. 88:1452-1459.) Key words: septic shock $\bullet$ inflammation $\bullet$ complement CR3
\end{abstract}

\section{Introduction}

Interleukin-1 (IL-1) occurs as $\alpha$ and $\beta$ polypeptides that activate specific receptors for IL-1 (IL-1R) ${ }^{1}$ (reviewed in reference

Dr. Fasano's present address is Department of Pediatrics, Johns Hopkins Medical Center, Baltimore, MD.

Address reprint requests to Dr. McCall, Section on Infectious Diseases, Bowman Gray School of Medicine, Medical Center Boulevard, Winston Salem, NC 27157-1042.

Received for publication 3 October 1990 and in revised form 11 June 1991

1. Abbreviations used in this paper: GM-CSF, granulocyte-macrophage/colony-stimulating factor; IL-2R, IL-2 receptor(s); rhIL-1, recombinant human IL-1; TNF $\alpha$, tumor necrosis factor- $\alpha$.

J. Clin. Invest.

(c) The American Society for Clinical Investigation, Inc.

0021-9738/91/11/1452/08 $\$ 2.00$

Volume 88, November 1991, 1452-1459
1). IL-1 exerts a wide range of biological effects on many cells. As a mediator of inflammation and host responses to infection, IL-1 has effects on thermoregulation, lymphocyte function, synthesis of acute phase proteins, production of arachidonic acid metabolites, granulocytosis, carbohydrate, and protein and lipid metabolism (2-4). The importance of IL-1 and tumor necrosis factor- $\alpha$ (TNF $\alpha)$ in the sepsis syndrome has recently been documented $(5,6)$, making the characterization of the IL-1R of prime importance. Recently, we (7) and others (8) reported that a single class of high-affinity IL-1R exists on the surface of circulating human neutrophils (PMN). Normal resting PMN express $\sim 700$ receptor sites per cell with an apparent $K_{\mathrm{d}}$ of $\sim 1.0 \mathrm{nM}$ as determined by saturation curves and Scatchard analysis of ${ }^{125} \mathrm{I}-\mathrm{IL}-1 \alpha$ binding. Based on cross-linking analysis, the IL-1R of the PMN has an apparent $M_{\mathrm{r}}$ of $\sim 68,000$, a value smaller than the IL-1R of T-cells and fibroblasts $\left(M_{\mathrm{r}} \sim 80,000\right)(9-12)$ but similar in size to the IL-1R of B-cells and monocytes (13-15).

Detectable levels of circulating TNF $\alpha$ and IL-1 occur in serum during sepsis in humans $(5,6)$ and both of these cytokines can mimic the sepsis syndrome in experimental animals (16-18). Children with severe meningococcemia and other forms of sepsis have elevated levels of TNF $\alpha$ and IL-1 in serum and the quantity of these circulating cytokines may correlate with the severity of the disease $(5,6)$.

We recently reported that normal human blood PMN synthesize IL- $1 \beta$ and IL $-1 \alpha$ in response to endotoxin or IL-1 itself (19). Synthesis of IL-1 $\beta$ by human PMN predominates over that of IL- $1 \alpha$ and IL- $1 \beta$, but little IL- $1 \alpha$ is secreted by these cells. Because of the potential importance of IL-1 in the sepsis syndrome, we studied the expression of IL-1R on human blood PMN obtained from patients with this highly lethal disseminated inflammatory process. We report that sepsis-PMN consistently express a marked increase in the number of IL-1R without a change in $K_{\mathrm{d}}$ (apparent $M_{\mathrm{r}} \sim 68,000$ ). The enhanced expression of IL-1R on sepsis-PMN occurs as a unimodal and homogenous event that is reversible, and it is not accompanied by increased expression of the complement receptor CR3. Enhanced expression of IL-1R on sepsis-PMN is not related simply to a state of myeloid stimulation. Marked amplification of IL-1R expression is not observed in other inflammatory processes, whether induced by infection or immunopathologic events.

\section{Methods}

Patient selection and chart review. Patients admitted to the Intensive Care Unit of the Wake Forest University Medical Center were screened for signs and symptoms of the sepsis syndrome, and then selected for entry into the study on the basis of the criteria of Bone et al. (20) (Table I). Patients with known immunodeficiencies (primary or secondary) were excluded from the study, as were trauma or burn victims within 1 wk of presentation. Once selected, informed consent was obtained 
Table I. Clinical Criteria for Enrollment of Subjects with the Sepsis Syndrome

Inclusion (all of the following) essentially as defined by Bone et al. (20):

(a) Clinically apparent focus of infection

(b) Fever $\left(>38.3^{\circ} \mathrm{C}\right.$, rectal) or hypothermia $\left(<35.6^{\circ} \mathrm{C}\right.$, rectal $)$

(c) Tachycardia: heart rate $>90$ beats/min

(d) Tachypnea: $>20$ spontaneous breaths per minute or a $\mathrm{P}_{\mathbf{a}} \mathrm{CO}_{2}$ $<32 \mathrm{mmHg}$

(e) Evidence of organ dysfunction-at least one of the following: Altered mentation (in relation to patient's baseline) Hypotension ( $<90 \mathrm{mmHg}$ systolic arterial pressure) Hypoxemia: $\mathrm{P}_{\mathrm{a}} \mathrm{O}_{2}<75 \mathrm{mmHg}$ on room air, or an equivalent oliguria: $<30 \mathrm{ml}$ or $<0.5 \mathrm{ml} / \mathrm{kg} \cdot \mathrm{h}$ for $>2 \mathrm{~h}$

Metabolic acidosis: elevated serum lactate $(>2.2 \mathrm{mg} / \mathrm{dl})$ or decreased serum bicarbonate ( $\leq 15 \mathrm{meq} /$ liter) with an anion gap of $>15$ accepted as criteria in the absence of a serum lactate level, unless the patient had chronic renal failure

from the patient or next of kin and $30-60 \mathrm{ml}$ of heparinized venous or arterial blood were drawn and delivered to the lab within 30 min. A venous blood sample was obtained simultaneously on healthy adults to serve as a source of control cells, and the samples were handled and processed in similar fashions. A chart review was conducted on all patients and data analysis conducted.

Neutrophil isolation. Human PMN (98-99\% pure) were isolated from heparinized venous or arterial blood using a modification of a previously described technique (21), with Isolymph (Gallard-Schlesinger Chemical Mfg. Corp., Carle Place, NY) sedimentation and gradient centrifugation, followed by hypotonic lysis of erythrocytes. The cells were suspended in sterile binding media (RPMI 1640, 5\% fetal calf serum, $25 \mathrm{mM}$ Hepes, $\mathrm{pH} 7.4$ ) at a concentration of $1.2-6.0 \times 10^{7}$ cells/ml and kept on ice until assayed. Cell viability using the trypan blue exclusion method remained unchanged over $8 \mathrm{~h}$. The percentage of early forms of PMN after isolation did not differ significantly from the whole blood differential.

Iodination of IL-1. Recombinant human IL-1 $\alpha$ (rhIL-1 $\alpha$ ) (a gift from Dr. Peter Lomedico, Hoffmann-LaRoche, Inc., Nutley, NJ or Drs. Steve Gillis and Steve Dower, Immunex Corp., Seattle, WA) was radioiodinated with carrier-free $\mathrm{Na}^{-125}$ I (Amersham Corp., Arlington Heights, IL) by using Enzymobeads (Bio-Rad Laboratories, Richmond, CA) as previously described by Paganelli-Parker et al. (8). The ${ }^{125}$ I-IL-1 $\alpha$ among preparations exhibited a specific activity of 30-70 $\mu \mathrm{Ci} / \mu \mathrm{g}$ of protein and retained $90 \%$ of its biological activity as measured by the D10.G4.1 murine co-mitogen assay. The radiolabeled protein was stored at $4^{\circ} \mathrm{C}$ and used within 3 wk.

${ }^{125} I-I L-1 \alpha$ radioreceptor binding assay. PMN from patients and controls and ${ }^{125} \mathrm{I}-\mathrm{IL}-1 \alpha$ at varying concentrations were incubated in binding media in a total volume of $150 \mu \mathrm{l}$ for $4 \mathrm{~h}$ at $4^{\circ} \mathrm{C}$ on a rocker platform (7). Nonspecific binding was measured by incubations in the presence of at least a 100 -fold molar excess of unlabeled rhIL-1 $\alpha$. Samples were performed in triplicate with variation in triplicate binding being $<10 \%$ in most instances. Cell-bound and free ${ }^{125} \mathrm{I}-\mathrm{IL}-1 \alpha$ were separated by centrifugation through $100 \mu$ l of a silicone oil mixture (1 part Thomas oil to 2 parts Gallard-Schlesinger oil). Tips containing pelleted cells and bound labeled protein were then counted on a gamma counter and Scatchard analysis of saturation curves was performed.

Internalization of human ${ }^{125} I-I L-1 \alpha$ in human PMN. $2 \times 10^{7}$ PMN were incubated with $5 \times 10^{-10} \mathrm{M}{ }^{125} \mathrm{I}-\mathrm{IL}-1 \alpha$ for $1 \mathrm{~h}$ at $4^{\circ} \mathrm{C}$ in the presence and absence of a 100 -fold excess of unlabeled rhIL-1 $\alpha$. Cells were washed twice in the binding medium to remove unbound IL- $1 \alpha$ and then placed at $37^{\circ} \mathrm{C}$. Aliquots were removed at the indicated times, centrifuged, and resuspended in $50 \mathrm{mM}$ glycine- $\mathrm{HCl}$ buffer (pH 3) containing $150 \mathrm{mM} \mathrm{NaCl}$ for $5 \mathrm{~min}$ at $4^{\circ} \mathrm{C}$. The cells were then sepa- rated from the buffer and released IL-1 was separated by centrifugation through silicone oil. Cell pellet and supernatant were recovered and counted.

Receptor sizing. PMN $\left(2 \times 10^{7}\right.$ cells $)$ from patients and controls were incubated with $5 \times 10^{-10} \mathrm{M}^{125} \mathrm{I}$-IL- $1 \alpha$ in the presence or absence of 100 -fold excess of unlabeled protein for $1 \mathrm{~h}$ at $4^{\circ} \mathrm{C}$. The cells were then washed twice with ice-cold phosphate-buffered saline (PBS) containing $1 \mathrm{mM} \mathrm{MgCl}$ at $\mathrm{pH} 8.5$ and then incubated at room temperature for $30 \mathrm{~min}$ with $0.15 \mathrm{mg} / \mathrm{ml}$ of the homobifunctional cross-linker, disuccidimidyl suberate (Pierce Chemical Co., Rockford, IL). The cells were then washed twice in PBS- $1 \mathrm{mM} \mathrm{MgCl}$ at $\mathrm{pH} 8.5$ buffer. After centrifugation, the entire cell pellet was resuspended in 10\% SDS in $0.06 \mathrm{M}$ Tris, $\mathrm{pH} 6.8$, boiled for $2 \mathrm{~min}$, and then centrifuged again. The cell supernatants were then stored overnight at $-20^{\circ} \mathrm{C}$. The following day the samples were suspended in $10 \%$ volume of treatment buffer containing 4\% SDS in $0.06 \mathrm{M}$ Tris buffer with glycerol and bromophenol blue, pH 6.8 , in the presence or absence of $2-\beta$-mercaptoethanol and boiled for an additional 2 min before being subjected to electrophoresis on a $7.5 \%$ polyacrylamide gel. Gels were then dried and exposed to film for up to $21 \mathrm{~d}$ at $-70^{\circ} \mathrm{C}$.

Flow cytometry. Cells were suspended in binding medium at a concentration of $2 \times 10^{6} \mathrm{cells} / \mathrm{ml}$ and incubated with $5 \times 10^{-10} \mathrm{M}$ unlabeled rhIL- $\alpha$ for $4 \mathrm{~h}$ at $4^{\circ} \mathrm{C}$. After three washes in binding medium, the cells were incubated sequentially with nonimmune goat IgG 1:100 dilution (a gift from Steve Kunkel, University of Michigan) for $30 \mathrm{~min}$, goat anti-human IL- $1 \alpha, 1: 100$ dilution, (a gift from Richard Chizzonite, Hoffmann-LaRoche, Inc.) for $60 \mathrm{~min}$, and fluorescein isothiocyanate (FITC)-conjugated anti-goat IgG-F(ab') , 1:10 dilution (Cappel Laboratories, Cooper Biomedical, Inc., Malvern, PA) for $30 \mathrm{~min}$. For evaluation of CR3, cells were incubated at $4^{\circ} \mathrm{C}$ for $30 \mathrm{~min}$ with a phycoerythrin conjugated anti-CR3 monoclonal antibody (Becton, Dickinson \& Co., Mountain View, CA) which recognizes the CD11b $\gamma$ subunit. Cells were washed twice in cold binding media between additions of the different antibody preparations. Cytofluorography was then performed on a FACS machine (Becton, Dickinson \& Co.) with separate gating for red and green fluorescence.

Statistical analysis. The nonpaired or paired, two-tailed, Student's $t$ test was employed for statistical analyses.

\section{Results}

Enhanced expression of the IL-1R on PMN from septic patients analyzed by ${ }^{125} I-I L-1 \alpha$ saturation curves. The number of IL-1 R sites per cell on human PMN from healthy volunteers and patients with the sepsis syndrome was quantitated using ${ }^{125} \mathrm{I}$ IL-1 binding studies and Scatchard analysis of saturation curves. 25 patients and 20 normal controls were studied. Normal PMN had $\sim 700$ IL-1R per cell with a $K_{\mathrm{d}}$ of $\sim 1.4 \mathrm{nM}$ (Fig. 1), a finding similar to that reported by Rhyne et al. (7) and Paganelli-Parker et al. (8). In contrast, sepsis-PMN had a dramatic increase in the sites per cell of IL-1R compared to normal PMN (Fig. 1, top). A wide variation in IL-1R sites per sepsis-PMN (2,100-50,000) was found among the patients, but in all cases receptor expression was markedly increased above control levels, with a mean of $9,329 \pm 2,212$ SE IL-1 R per cell on sepsis-PMN and 716 \pm 42 SE IL-1R per cell on normal PMN $(P<0.001)$. No apparent difference in the $K_{\mathrm{d}}$ of IL-1R was noted between the sepsis-PMN (mean $=1.34 \mathrm{nM} \pm 0.25 \mathrm{SE}$ ) and normal PMN (mean = 1.43 $\mathrm{nM} \pm 0.09 \mathrm{SE})$ (Fig. 1, bottom).

A patient with the sepsis syndrome followed over time is shown in Fig. $2 \mathrm{~A}$. A marked elevation in the number of sites per PMN of IL-1R was present at the outset $(\sim 9,000)$. This patient had organ failure (brain and cardiovascular failure) only during the first $5 \mathrm{~d}$ of study. The increased expression of IL-1R returned to normal after organ failure subsided; the $K_{\mathrm{d}}$ 

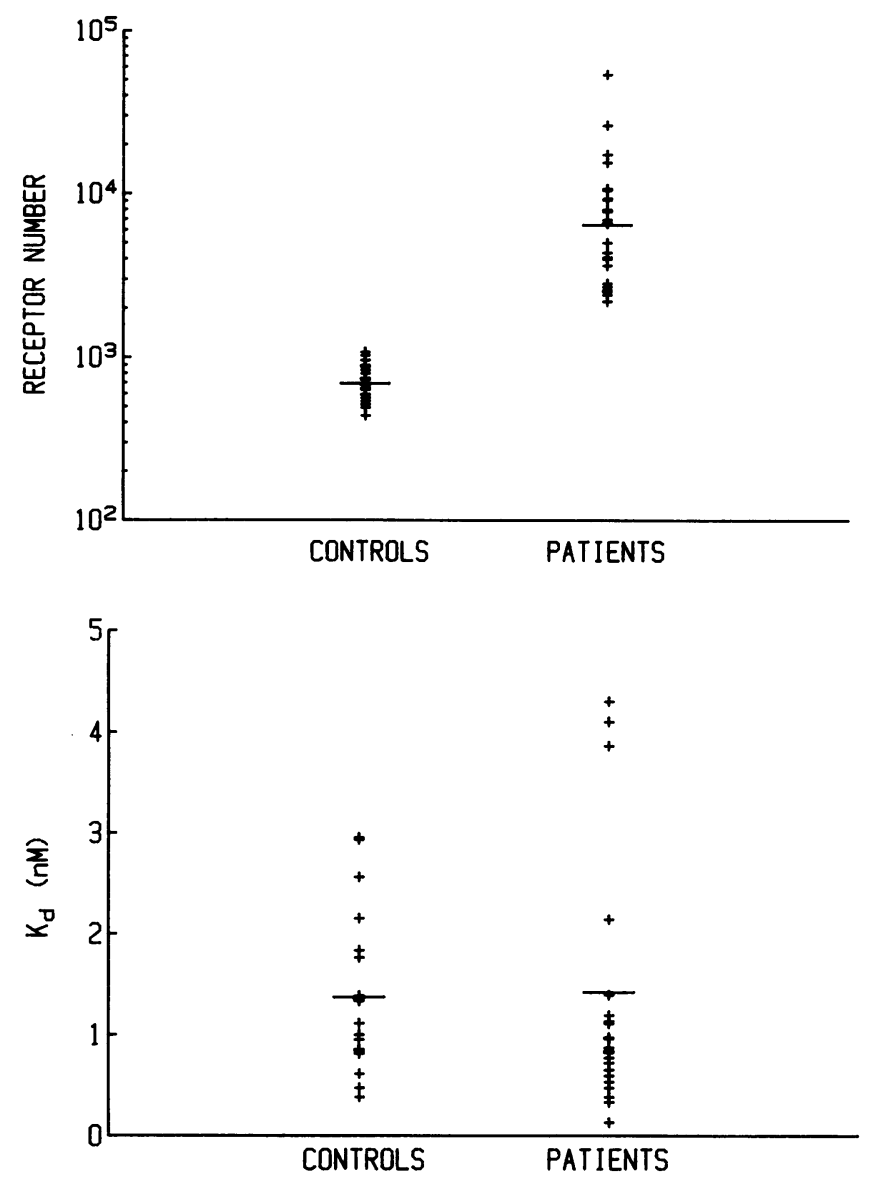

Figure 1. Expression of IL-1R on sepsis- vs. normal PMN. (Top) Scatter plot of sites per cell of IL-1R expressed on human PMN from 25 patients with the sepsis syndrome and from 20 controls. IL-1R sites per cell were determined by Scatchard analysis of saturation curves. Patient mean $=9,329 \pm 2,212 \mathrm{SE}$; control mean $=716 \pm 44 \mathrm{SE}$ $(P<0.001)$. (Bottom) Scatter plot of IL-1R dissociation constant $\left(K_{d}\right)$ on PMN from patients with the sepsis syndrome and controls. The $K_{\mathrm{d}}$ was determined from Scatchard analysis of saturation curves. Patient mean $=1.34 \mathrm{nM} \pm 0.25 \mathrm{SE}$; control mean $=1.43 \mathrm{nM} \pm 0.09 \mathrm{SE}$ $(P>0.5)$

of IL-1R was always similar to that of normal PMN (not shown).

Another patient was studied before, during and after the sepsis syndrome. We first evaluated IL-1R in this patient when there was marked elevation in temperature $\left(104^{\circ} \mathrm{F}\right)$ and no apparent infection (fever was felt to be due to a drug reaction or an alteration in thermal regulation). The patient then developed the sepsis syndrome with hypotension and the acute respiratory distress syndrome, and later recovered. IL-1R on PMN was evaluated at the three different phases of illness and the results are shown in Fig. $2 B$. Normal expression of IL-1R was seen when there was high fever and no infection; IL-1R expression increased during the sepsis syndrome and rapidly returned to normal after recovery.

Analysis of patient data. In reviewing patient characteristics, no correlation could be found between the magnitude of the enhanced IL-1R expression and patient age (age range 15$101 \mathrm{yr}$ ), sex, race, the level of temperature, total white blood cells, absolute PMN count, presence of band-forms (range $<5 \%$ to $>30 \%$ ), blood pressure, number of organs in failure,
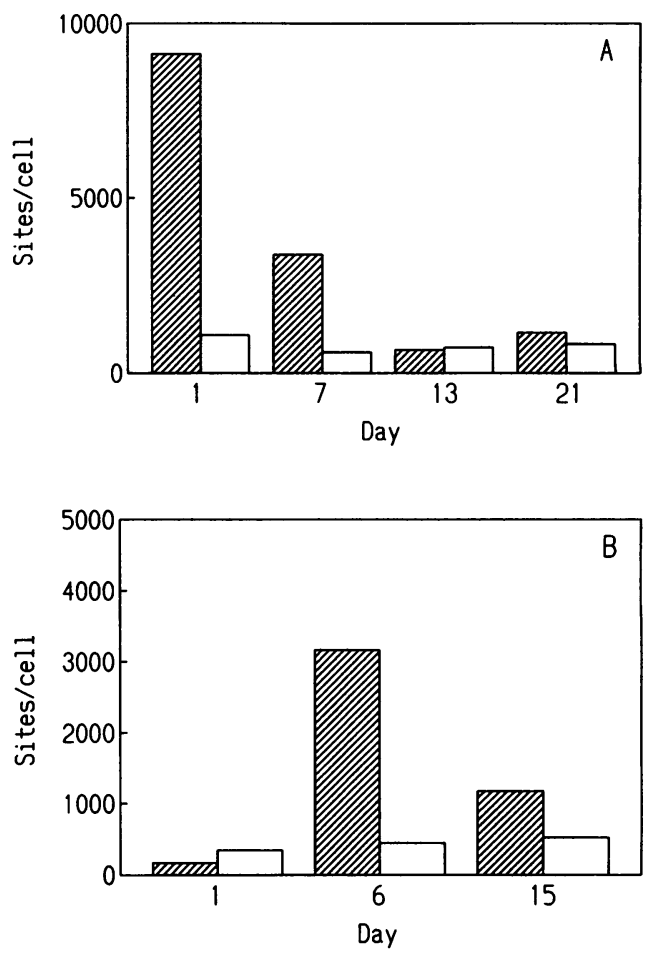

Figure 2. Longitudinal studies of IL-1R expression on PMN from patients with the sepsis syndrome. $(A)$ A patient studied during and after recovery of the sepsis syndrome. Values are expressed as sites per cell of patient (hatched bars) or control (open bars) PMN. The patient had organ failure (brain and cardiovascular) only during the first $5 \mathrm{~d}$ of study. (B) A patient studied before, during, and after resolution of the sepsis syndrome. When first studied the patient had daily temperatures of $104^{\circ} \mathrm{F}$ without apparent infection. The second analysis was performed when the patient had the sepsis syndrome (hypotension and the adult respiratory distress syndrome). The third analysis was after recovery of hypotension and adult respiratory distress syndrome.

organism responsible for infection (gram-positive or gramnegative bacteria, and fungi [Candida species] were causal), location of infection, culture of microbes from the blood, use of vasopressors, or patient outcome. There was no apparent relationship between sites per cell of IL-1R and the time the blood sample was obtained with respect to onset of the sepsis syndrome. The earliest that a patient was studied after onset of the sepsis syndrome was $\sim 8 \mathrm{~h}$, but virtually all patients were first studied within $72 \mathrm{~h}$ of onset.

Expression of $I L-1 R$ in other states of inflammation and myeloid stimulation. We next determined if amplified expression of IL-1R might discriminate the sepsis syndrome from other states of inflammation and myeloid stimulation. We divided patients into the following categories: (a) disseminated inflammation (fever, leukocytosis) without apparent infection but with organ failure; $(b)$ disseminated inflammation with infection and without organ failure; $(c)$ disseminated inflammation without infection or organ failure; $(d)$ local inflammation without infection or fever. The results are shown in Table II. Of particular note: (a) the four patients with disseminated inflammation without infection but with organ failure had a mean of $1,467 \pm 308$ SD IL-1R sites per PMN, a value significantly above normal $(P<0.01)$ but significantly below sepsis-PMN $(P$ $<0.001)$; (b) the four patients with either active systemic lupus 
Table II. IL-1 R Expression on PMN from Different States of Inflammation and Myeloid Stimulation

\begin{tabular}{|c|c|}
\hline Condition & IL-1 R sites/cell \\
\hline Normal & 716 (42 SE) \\
\hline Septic shock & $9,329(2,212 \mathrm{SI}$ \\
\hline \multicolumn{2}{|l|}{$\begin{array}{l}\text { Disseminated inflammation without } \\
\text { infection, with organ failure }\end{array}$} \\
\hline Systemic lupus: liver/renal failure & 1,408 \\
\hline Acute pancreatitis: liver/renal failure & 1,143 \\
\hline Dilantin syndrome: liver/renal failure & 1,430 \\
\hline Hypersensitivity angiitis/renal failure & 1,886 \\
\hline \multicolumn{2}{|l|}{$\begin{array}{l}\text { Disseminated inflammation with infection, } \\
\text { but without septic shock }\end{array}$} \\
\hline Pneumonia, mixed gram-negative & 1,000 \\
\hline Pneumonia, pneumococcal & 460 \\
\hline Acute bacterial cellulitis & 600 \\
\hline \multicolumn{2}{|l|}{$\begin{array}{l}\text { Disseminated inflammation without } \\
\text { infection or organ failure }\end{array}$} \\
\hline Drug reaction, fever, and rash & 250 \\
\hline Drug reaction, fever and rash & 500 \\
\hline Drug reaction, fever, and rash & 600 \\
\hline \multicolumn{2}{|l|}{$\begin{array}{l}\text { Local inflammation without infection or } \\
\text { fever }\end{array}$} \\
\hline Systemic lupus, active arthritis & 163 \\
\hline Systemic lupus, active glomerulonephritis & 210 \\
\hline Rheumatoid arthritis, active & 360 \\
\hline Rheumatoid arthritis, active & 210 \\
\hline Psoriasis & 1,279 \\
\hline \multicolumn{2}{|l|}{ Myeloid stimulation without inflammation } \\
\hline Chronic granulocytic leukemia & 569 \\
\hline Chronic granulocytic leukemia & 109 \\
\hline Polycythemia vera & 870 \\
\hline
\end{tabular}

erythematosus $(n=2)$ or rheumatoid arthritis $(n=2)$ but without infection or fever had a mean of $236 \pm 86$ SD IL-1 $R$ per cell, a value significantly lower than that of normal PMN ( $P$ $=<0.01) ;(c)$ no patient in any group exceeded $2,100 \mathrm{IL}-1 \mathrm{R}$ sites per PMN of IL-1R, a value below the lowest value of the range of IL-1R observed on sepsis-PMN. One of the two patients with acute granulocytic leukemia (untreated and with $\sim 20 \%$ blast forms and $<10 \%$ mature PMN) had a low number of IL-1R ( 109 sites per PMN).

Internalization of ${ }^{125} I-I L-1$ on sepsis-PMN. Fig. 3 shows the rate of internalization of ${ }^{125}$ I-IL-1 bound to sepsis-PMN. $50 \%$ internalization of ligand was observed by $30 \mathrm{~min}$, a value like that we reported for normal PMN (7).

Effects of granulocyte-macrophage/colony-stimulating factor (GM-CSF) on IL-IR expression on normal PMN. Since myeloid stimulation per se did not appear to be responsible for increased expression of IL-1R on sepsis-PMN and the rate of internalization of ${ }^{125} \mathrm{I}-\mathrm{IL}-1 \alpha$ (and presumably IL-1R) was normal, we wondered whether normal blood PMN are capable of increasing the expression of IL-1R in vitro. PMN isolated from venous blood from healthy volunteers $(n=4)$ were incubated for $18 \mathrm{~h}$ at $4^{\circ} \mathrm{C}$ or $37^{\circ} \mathrm{C}$ with or without $100 \mathrm{U} / \mathrm{ml}$ of recombi-

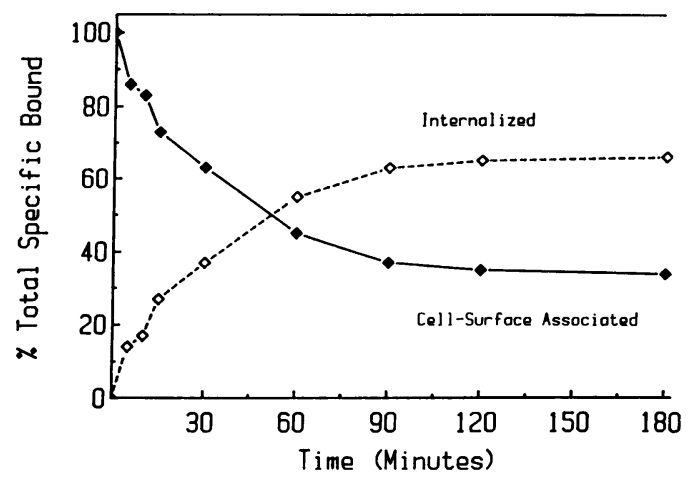

Figure 3. Rate of internalization of ${ }^{125} \mathrm{I}-\mathrm{IL}-1 \alpha$ in sepsis-PMN. PMN were first incubated at $4^{\circ} \mathrm{C}$ for $1 \mathrm{~h}$ with ${ }^{125} \mathrm{I}-\mathrm{IL}-1 \alpha$ with or without 100 -fold excess of cold rhIL-1 $\alpha$. Cells were then warmed to $37^{\circ} \mathrm{C}$ for varying times, cooled to $4^{\circ} \mathrm{C}$, and washed in glycine- $\mathrm{HCl}$ buffer $(\mathrm{pH}$ 3 ) to remove externally bound IL- $1 \alpha$ before counting internalized ${ }^{125} \mathrm{I}$-IL-1 $\alpha$.
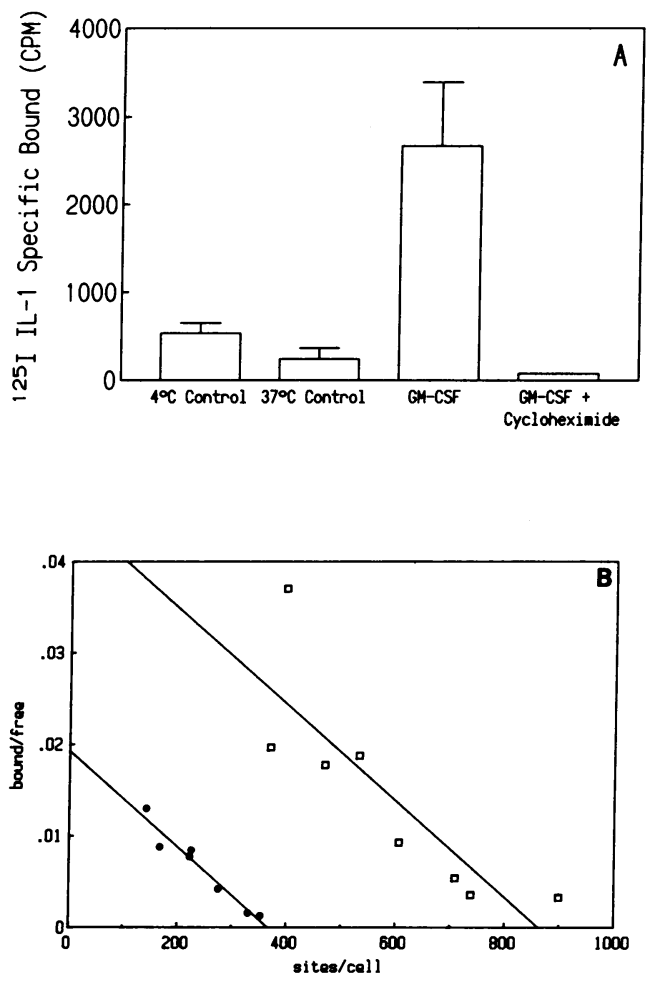

Figure 4. Effect of in vitro administered rhGM-CSF on the expression of IL-1R of normal PMN. (A) PMN incubated with $100 \mathrm{U} / \mathrm{ml}$ rhGM-CSF for $18 \mathrm{~h}$ at $37^{\circ} \mathrm{C}$. Controls were maintained at either $4^{\circ} \mathrm{C}$ or $37^{\circ} \mathrm{C}$ for $18 \mathrm{~h}$ in the absence of rhGM-CSF. Values are expressed as counts per minute specific binding $\pm \mathrm{SE}$ of $n=4$ experiments performed in triplicate. The difference between the means of $4^{\circ} \mathrm{C}$ control and $37^{\circ} \mathrm{C}$ untreated control vs. rhGM-CSF are $P<0.01$ and $P<0.01$, respectively. The last bar is the mean of two experiments showing the effect of $5 \mu \mathrm{g} / \mathrm{ml}$ of cycloheximide on up-regulation of IL-1R by rhGM-CSF. $(B)$ Scatchard analysis of a representative experiment showing control PMN or PMN incubated at $37^{\circ} \mathrm{C}$ for $18 \mathrm{~h}$ with 100 $\mathrm{U} / \mathrm{ml}$ of rhGM-CSF. No specific binding was detected in the control PMN incubated for $18 \mathrm{~h}$ at $37^{\circ} \mathrm{C}$ in the absence of rhGM-CSF (not shown). 
nant human GM-CSF (rhGM-CSF) (Cistron Corp, Pine Brook, NJ) and analyzed for binding of ${ }^{125} \mathrm{I}-\mathrm{IL}-1 \alpha$. As shown in Fig. $4 A$, PMN incubated at $37^{\circ} \mathrm{C}$ for $18 \mathrm{~h}$ without rhGM-CSF had reduced specific binding of ${ }^{125}$ I-IL- $1 \alpha$ when compared with a $4^{\circ} \mathrm{C}$ control. In contrast, PMN incubated with rhGM-CSF had an increase in specific binding at $18 \mathrm{~h}(P<0.01)$, and this increase could be almost totally inhibited by $5 \mu \mathrm{g} / \mathrm{ml}$ of cycloheximide, suggesting that synthesis of IL-1R occurred rather than alterations in recycling of previously synthesized receptors. Shown in Fig. $4 B$ is a Scatchard analysis. There was an increase in IL-1R induced by rhGM-CSF from 400 IL-1R sites per cell in control PMN held at $4^{\circ} \mathrm{C}$ for $18 \mathrm{~h}$ to $\sim 800$ sites per cell of IL-1R in PMN treated with rhGM-CSF for $18 \mathrm{~h}$ at $37^{\circ} \mathrm{C}$; no change in $K_{\mathrm{d}}$ occurred. In this experiment, no specific binding was detected in the PMN incubated without rhGM-CSF for $18 \mathrm{~h}$ at $37^{\circ} \mathrm{C}$.

Cytofluorographic analysis of $I L-1 R$ and $C R 3$ expression on sepsis-PMN. Enhanced expression of the complement receptor CR3 on human blood PMN has been reported after burn injuries $(22,23)$ and in vitro after warming of cells to $37^{\circ} \mathrm{C}$ (24). To determine if increased expression of IL-1 R is accompanied by an increase in CR3 expression, or if receptor up-regulation on sepsis-PMN is unimodal, we used flow cytometry to simultaneously analyze both CR3 and IL-1R on PMN from three septic patients and three controls. A unimodal increase in expression of IL-1R was observed on sepsis-PMN vs. normal PMN (Fig. $5 \mathrm{~A}$ ). In contrast, no increase in the expression of CR3 was observed on sepsis-PMN with increases in expression of IL-1R (Fig. 5 B). As a further control, we determined that the antibody to the CD1 $1 \mathrm{~b} \gamma$ chain of $\mathrm{CR} 3$ could detect upregulation of CR3 on normal PMN stimulated by either $N$-formyl-methionyl-leucyl-phenylalanine or bacterial lipopolysaccharide (not shown).

An increased quantity of the low molecular weight form of $I L-1 R$ is expressed on sepsis-PMN. The size of the IL-1R was evaluated on PMN from three patients with the sepsis syndrome and three controls using crosslinking, solubilization, and electrophoresis. In all instances, a major band was observed with an apparent $M_{\mathrm{r}}$ of $\sim 68,000$ when corrected for bound IL-1 $\alpha$. An example is shown in Fig. 6. The bands observed were similar in $M_{\mathrm{r}}$ to those observed on normal PMN, but were of much stronger intensity in patients $(C)$ than in controls $(A)$. Bands with a higher $M_{\mathrm{r}}$ were always seen, perhaps representing aggregated IL-1R or IL-1R associated with other cellular proteins; lower $M_{\mathrm{r}}$ bands were not always detected and could represent proteolytic cleavage or a different species of IL-1R. Precise loading of a single lane was impossible so "overflow" of bands into adjacent lanes could not be avoided. All cross-linked bands could be completed by unlabeled IL-1 $\alpha$ (B and $D$ ).

\section{Discussion}

PMN obtained from the peripheral blood of patients with the sepsis syndrome consistently have a unimodal increase in the number of IL-1R expressed on their surfaces with a normal $K_{d}$ (Fig. 1). IL-1R expression on PMN returns to normal within a few days after resolution of the sepsis syndrome (Fig. 2). An increase in expression of IL-1R on sepsis-PMN was demonstrated by three methods, including saturation curves of ${ }^{125} \mathrm{I}$ -
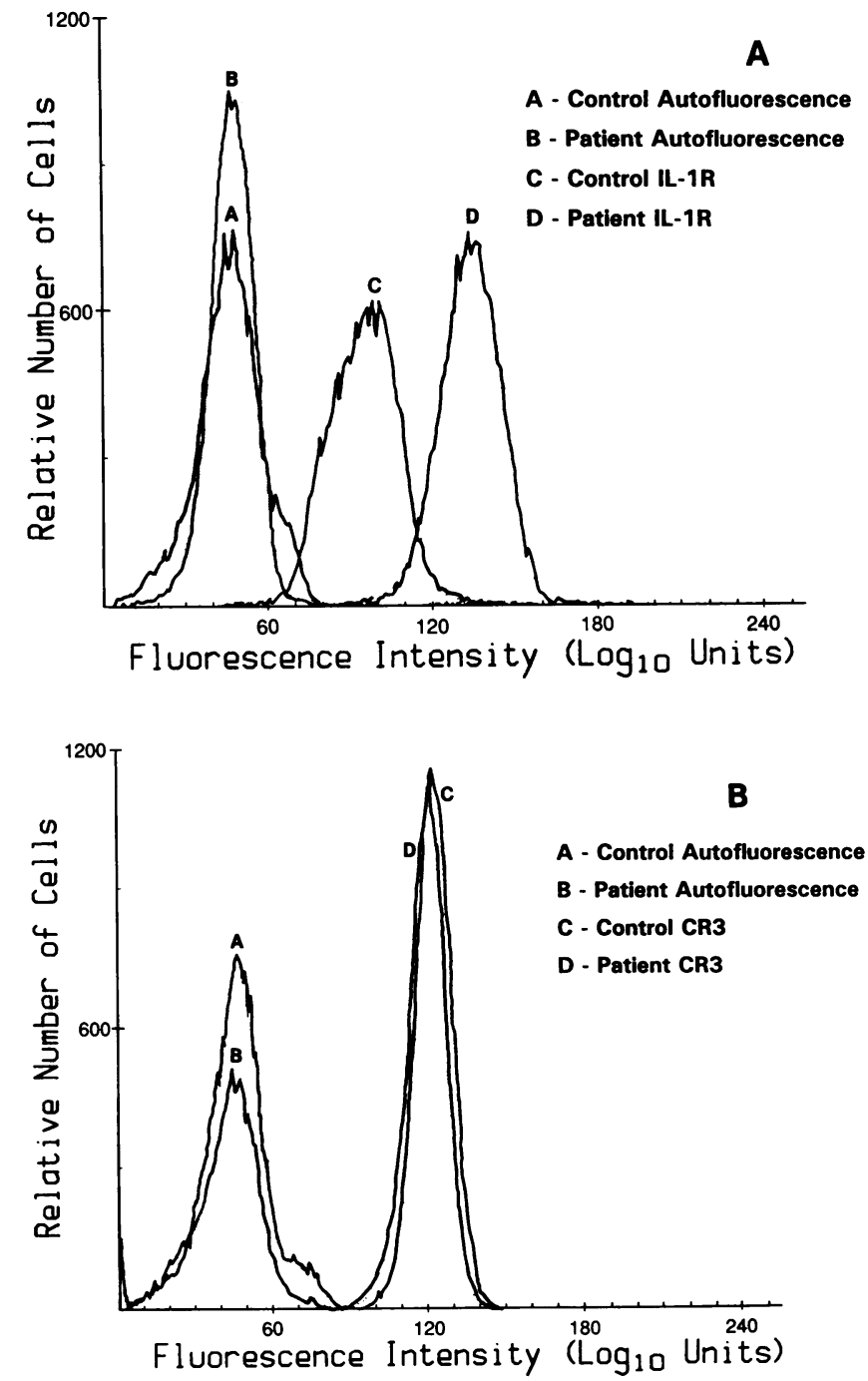

Figure 5. Cytofluorographic analysis of expression of IL-1R and CR3 on sepsis- and normal PMN. Fluorescence histograms of FACS analysis of PMN from a representative of three experiments of sepsisPMN and normal PMN after staining with fluorescein or phycoerythrin-conjugated antibodies to detect IL-1R $(A)$ and CR3 $(B)$, respectively. All 3 patients studied had a unimodal increase in IL-1R with no detectable change in CR3.

IL-1 $\alpha$ and Scatchard analysis, flow cytometry, and cross-linking of ${ }^{125} \mathrm{I}-\mathrm{IL}-1 \alpha$ bound to IL-1R. Surprisingly, all 25 patients studied had an elevation in the number of IL-1R expressed per sepsis-PMN, suggesting that high levels of IL-1R expression of PMN might be a useful marker for the sepsis syndrome. Moreover, our investigation of IL-1R expression on blood PMN obtained from other states of inflammation and myeloid stimulation suggests that the level of expression of IL-1R may discriminate among various disease categories (Table II). Of particular note is our observation that PMN from patients with acute disseminated inflammation and organ failure not caused by infection do not express the high number of IL-1R sites per cell that are found on sepsis-PMN, although their values are higher than normal PMN. Furthermore, infections without organ failure but with signs of systemic inflammation such as fever and 


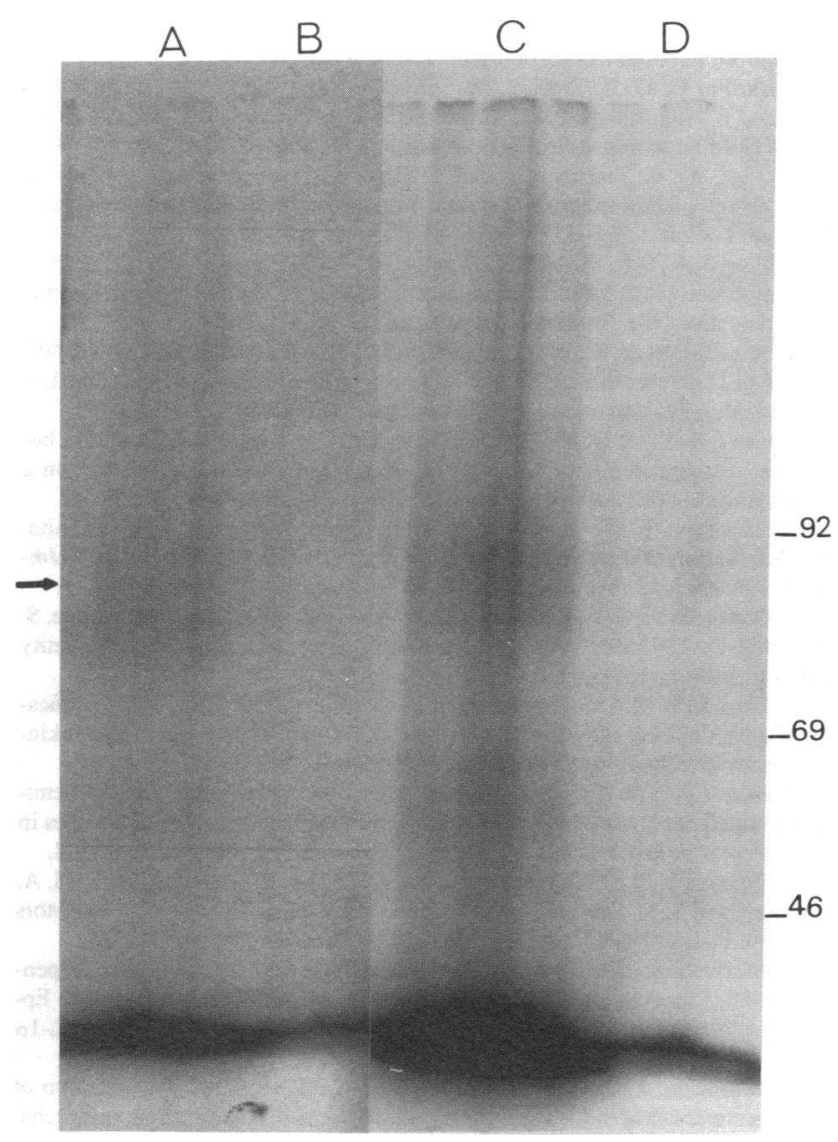

Figure 6. SDS-PAGE analysis of co-valently cross-linked IL-1R and ${ }^{125}$ I-IL-1 on sepsis and normal PMN with and without competition by rhIL-1 $\alpha$. $(A)$ Normal PMN without competition. (B) Normal PMN with competition. (C) Sepsis-PMN without competition. (D) SepsisPMN with competition. The molecular weight standards are shown in the right margin (in thousands). The arrow on the left is thought to represent the IL-1R with an $M_{\mathrm{r}}$ of $\sim 68,000$. Normal and sepsisPMN were studied in parallel, but the film of the normal PMN was exposed for $30 \mathrm{~d}$ and that of sepsis-PMN for $7 \mathrm{~d}$.

leukocytosis appear not to be associated with increases in IL$1 R$, and active inflammatory processes such as systemic lupus erythematosus and rheumatoid arthritis may be accompanied by a decrease in expression of IL-1R on circulating PMN. We emphasize that more patients among various types of inflammatory processes must be studied before the actual sensitivity and specificity of IL-1R expression on PMN can be established as the indicator for these diseases.

The increased expression of IL-1R on circulating PMN during the sepsis syndrome surprised us in that we had originally hypothesized that PMN from these patients would have a decrease in expression of IL-1R, because sepsis is often associated with circulation of IL-1 as well as other cytokines such as TNF $\alpha$ (5, 6, and reviewed in reference 25). Circulating IL-1 would be expected to homologously down-regulate the IL-1R of PMN, and circulation of TNF $\alpha$ might reduce IL-1R by heterologous down-regulation. Indeed, we have found that homologous down-regulation of IL-1 occurs in vitro after stimulation of normal PMN with IL-1 (7), and heterologous down-regula- tion of IL-1R is induced by many stimuli, including endotoxin, FMLP, and TNF $\alpha(7,26)$. We cannot explain the apparent paradox of increased expression of IL-1R on sepsis-PMN. Although we do not know if the patients we studied had circulating IL-1 or TNF $\alpha$, elevations in plasma IL-1 and TNF $\alpha$ would be expected in some of our patients.

The $M_{\mathrm{r}}$ of IL-1R expressed on sepsis-PMN is the same as that found on normal PMN, further establishing that PMN express a lower $M_{\mathrm{r}}$ form of IL-1R. At least two forms of IL-1R are expressed on cells $(1,27)$. One has a $M_{\mathrm{r}}$ of $80,000(7,8,14$, $15)$ and is found on T-cells and cells derived from mesenchyme, such as fibroblasts and synovial cells (9-13); another is a lower $M_{\mathrm{r}}$ IL-1R $(60,000-70,000)$ found on B cells, monocytes, and PMN $(7,8,14,15)$. The high and low $M_{\mathrm{r}}$ forms of IL-1R are now referred to as types 1 and 2 IL-1R, respectively, and they appear to be products of separate genes $(14,28)$. Types 1 and 2 IL-1R differ not only in $M_{\mathrm{r}}$ but in the transductional events linked to functional responses of cells stimulated by IL-1 (13).

Another surprising finding in this study is that the increased expression of IL-1R on sepsis-PMN is not associated with an increase in expression of complement receptor CR3. Increased expression of CR3 has been reported on blood PMN obtained from patients with the inflammation of burn injury $(22,23)$, on PMN in exudates $(29,30)$, and on blood PMN of patients with systemic lupus erythematosus (31). Although we observed no change in CR3 expression on sepsis-PMN, the increased expression of specific receptors on sepsis-PMN is not limited to IL-1R. We also have observed a unimodal increase in expression of the receptor for TNF $\alpha$ on sepsis-PMN in 11 of 11 patients with the sepsis syndrome (32); sepsis-PMN from these patients also had no change or a decrease in expression of the CR3 receptor. We have found that agents that enhance the expression of CR3 on normal PMN in vitro always concomitantly induce a rapid down-regulation of the IL-1R (26). A somewhat analogous finding of discordant expression of receptors on human PMN was reported for C5a and the receptors CR1, CR3, Fc $\gamma$ R III, and FMLP (33). Apparently, the expressions of IL-1, TNF $\alpha$, and C5a receptors on PMN are under different controls than the other receptors, and up-regulation of some receptors may be associated with down-regulation of others.

We have not clearly identified the mechanism responsible for enhanced expression of IL-1R on sepsis-PMN. Two anatomical sites might possibly regulate expression of IL-1R, the bone marrow and the peripheral circulation. Our data (Table II) suggest that myeloid stimulation in the presence or absence of severe systemic inflammation is not a sufficient stimulus to induce up-regulation of IL-1R. Our finding that the IL-1 R expression increases in normal PMN incubated with rhGM-CSF in vitro, and that this increase is inhibited by cycloheximide, suggests that enhanced expression of IL-1R on sepsis-PMN could depend on events that take place in the peripheral circulation and that require protein synthesis. However, it is unlikely that GM-CSF alone would be the agonist responsible for increased expression of IL-1R, since the increase in number of IL-1 R induced by rhGM-CSF on normal PMN was well below that found in sepsis-PMN and increases in circulating GMCSF have not to our knowledge been reported in the sepsis syndrome. Other stimuli released during the sepsis syndrome, 
either alone or acting together, might amplify expression of the IL-1R gene. For example, Spriggs et al. recently reported that the steroid dexamethasone and prostaglandin $\mathrm{E}_{2}$ used together markedly enhance expression of the low $M_{\mathrm{r}}$ II-1 R expressed on human monocytic cells (34). Dr. Spriggs has also found that stimulation of normal human PMN in vitro with dexamethasone and prostaglandin $\mathrm{E}_{2}$ causes a significant increase in the expression of IL-1R (personal communication).

The functional responses of normal PMN to stimulation of IL-1 R by IL-1 appear to be tightly controlled. We (7, and unpublished observations) and others (35) have found that IL-1 stimulation of normal human PMN does not induce early responses of PMN such as NADPH oxidase-activation, degranulation, chemotaxis, translocation of protein kinase $\mathrm{C}$, activation of phospholipase $\mathbf{C}$ for phosphatidylinositol or phospholipase $\mathrm{D}$ for choline-containing phosphoglycerides, or increases in free intracellular calcium. However, IL-1R of normal PMN responds to stimulation by IL-1 by inducing synthesis of both IL $-1 \alpha$ and $\beta$ proteins $(19,36)$, as well as TNF $\alpha$ (unpublished observations). We were unable to evaluate the function of the IL-1R on sepsis-PMN in this study because of limitations on blood procurement, so we do not know whether the increased expression of IL-R on sepsis-PMN is associated with an alteration in PMN responses which follow stimulation by IL-1.

In summary, the sepsis syndrome of humans is consistently associated with marked increases in the number of IL-1R expressed on circulating PMN, without a change in its $M_{\mathrm{r}}$ or $K_{\mathrm{d}}$. The increase in IL-1R is unimodally distributed on all sepsis$P M N$. In contrast, sepsis-PMN have no increase in expression of CR3. Our limited study of other states of inflammation and myeloid stimulation suggests that amplified expression of IL$1 \mathrm{R}$ on blood PMN might discriminate the sepsis syndrome from other diseases. The mechanism responsible for enhanced expression of IL-1R on sepsis-PMN is unknown, but we speculate that it follows an event or events which induce synthesis of IL-1R in PMN and that occurs, at least in part, in the peripheral circulation. The functional significance of this phenotypic change of PMN during the sepsis syndrome is unknown.

\section{Acknowledgments}

We thank Mary Green for administrative and secretarial assistance, Lynell Grosso-Wilmoth for technical support, Dr. Steve Mizel for helpful suggestions, and Clayton Fletcher for performing the FACS analysis. We are especially grateful to Steve Kunkel (University of Michigan), Peter Lomedico and Richard Chizzonite (Hoffmann-LaRoche, Inc.), and Steve Gillis and Steve Dower (Immunex Corp.), who supplied us with the reagents described in the text.

This work was supported by U. S. Public Health Service grants AI-09169 and HL-29293 awarded by the National Institutes of Health to Dr. McCall. The Flow Cytometry Core facility of the Comprehensive Cancer Center of Wake Forest University is supported by National Institutes of Health grant CA-12197.

\section{References}

1. Dinarello, C. A., B. D. Clark, A. J. Puren, N. Savage, and P. M. Rosoff. 1989. The interleukin 1 receptor. Immunol. Today. 10:49-51.

2. Dinarello, C. A. 1988. Biology of interleukin 1. FASEB (Fed. Am. Soc. Exp. Biol.) J. 2:108-115.

3. Dinarello, C. A. 1984. Interleukin 1. Rev. Infect. Dis. 6:51-95.
4. Oppenheim, J. J., E. J. Kovacs, K. Matsushima, and S. K. Durum. 1986. There is more than one IL-1. Immunol. Today. 7:45-56.

5. Girardin, E., G. E. Graw, J. M. Dayer, P. Roux-Lombard, The J5 Study Group, and P. H. Lambert. 1988. Tumor necrosis factor and interleukin-1 in the serum of children with severe infectious purpura. N. Engl. J. Med. 319:397-400.

6. Waage, A., A. Halstensen, and T. Espevik. 1987. Association between tumour necrosis factor in serum and fatal outcome in patients with meningococcal disease. Lancet. 1:355-357.

7. Rhyne, J. A., S. B. Mizel, R. G. Taylor, M. Chedid, and C. E. McCall. 1988. Characterization of the human interleukin-1 receptor on human polymorphonuclear leukocytes. Clin. Immunol. Immunopathol. 48:354-361.

8. Paganelli-Parker, K., W. R. Benjamin, K. L. Kaffka, and P. L. Kilian. 1989. Presence of IL-1 receptors on human and murine neutrophils: relevance to IL-1 mediated effects in inflammation. J. Immunol. 142:537-542.

9. Dower, S. K., S. M. Call, S. Gillis, and D. L. Urdal. 1986. Similarity between the interleukin-1 receptors on a murine T-lymphoma cell line and on a murine fibroblast cell line. Proc. Natl. Acad. Sci. USA. 83:1060-1064.

10. Shirakawa, F., Y. Tanaka, T. Ota, H. Suguki, S. Eto, and U. Yamashita. 1987. Expression of interleukin-1 receptors on human peripheral T cells. J. Immunol. 138:4243-4248.

11. Dower, S. K., S. R. Kronheim, C. J. March, P. J. Conlon, T. P. Hoppe, S. Gillis, and D. L. Urdal. 1985. Detection and characterization of high-affinity plasma membrane receptors for interleukin 1. J. Exp. Med. 162:501-515.

12. Chin, J., P. M. Caneraon, E. A. Rupp, and J. A. Schmidt. 1987. Identification of a high affinity receptor for native human interleukin- $\beta$ and interleukin$1 \alpha$ on normal human lung fibroblasts. J. Exp. Med. 165:70-86.

13. Horuk, R., J. J. Huang, M. Covington, and R. C. Newton. 1987. Biochemical and kinetic analysis of the interleukin-1 receptor: evidence for differences in the molecular properties of IL-1 receptors. J. Biol. Chem. 262:16275-16278.

14. Bomsztyk, K., J. E. Sims, T. H. Stanton, J. Slack, C. J. McMahan, M. A. Valentine, and S. K. Dower. 1989. Evidence for different interleukin 1 receptors in murine B- and T-cell lines. Proc. Natl. Acad. Sci. USA. 86:8034-8038.

15. Matsushima, K., T. Akahoshi, M. Yamada, Y. Furutani, and J. J. Oppenheim. 1986. Properties of a specific interleukin 1 (IL-1) receptor on human Epstein Barr virus-transformed B lymphocytes: identity of the receptor for IL-1a and IL-1B. J. Immunol. 136:4496-4502.

16. Mathison, J. C., E. Wolfson, and R. J. Ulevitch. 1988. Participation of tumor necrosis factor in the mediation of gram negative bacterial lipopolysaccharide-induced injury in rabbits. J. Clin. Invest. 81:1925-1937.

17. Tracey, K. J., Y. Fong, D. G. Hesse, K. R. Manogue, A. T. Lee, G. C. Kuo, S. F. Lowry, and A. Cerami. 1987. Anti-cachetcin/TNF monoclonal antibodies prevent septic shock during lethal bacteraemia. Nature (Lond.). 330(6149): 662-664.

18. Tracey, K. J., S. F. Lowry, T. J. Fahey III, J. D. Albert, Y. Fong, D. Hesse, B. Beutler, K. R. Manoque, S. Calvano, and H. Wei. 1987. Cachectin/tumor necrosis factor induces lethal shock and stress hormone responses in the dog. Surg. Gynecol. Obstet. 164:415-422.

19. Lord, P. C. W., L. M. G. Wilmoth, S. B. Mizel, and C. E. McCall. 1991. Expression of IL $-\alpha$ and $\beta$ genes by human blood polymorphonuclear leukocytes. J. Clin. Invest. 87:1312-1321.

20. Bone, R. C., C. J. Fisher, Jr., T. P. Clemmer, G. J. Slotman, C. A. Metz, and R. A. Balk. 1987. A controlled clinical trial of high-dose methylprednisolone in the treatment of severe sepsis and septic shock. N. Engl. J. Med. 317:653-658.

21. McPhail, L., and R. Snyderman. 1983. Activation of the respiratory burst enzyme in human polymorphonuclear leukocytes by chemoattractants and other soluble stimuli: Evidence that the same oxidase is activated by different transductional mechanisms. J. Clin. Invest. 72:192-200.

22. Moore, F. D., Jr., C. Davis, M. Rodrick, J. A. Mannick, and D. T. Fearon 1986. Neutrophil activation in thermal injury as assessed by increased expression of complement receptors. N. Engl. J. Med. 314:948-953.

23. Nelson, R. D., S. R. Hasslen, D. H. Ahrenholz, E. Haus, and L. D. Solem 1986. Influence of minor thermal injury on expression of complement receptor CR3 on human neutrophils. Am. J. Pathol. 125:563-570.

24. Berger, M. J. O'Shea, A. S. Cross, T. M. Folks, T. M. Chused, E. J. Brown, and M. M. Frank. 1984. Human neutrophils increase expression of C3bi as well as C3b receptors upon activation. J. Clin. Invest. 74:1566-1571.

25. Parillo, J. E., M. M. Parker, C. Natanson, A. F. Suffredini, R. L. Danner, R. E. Cunnion, and F. P. Ognibene. 1990. Septic shock in humans. Ann. Intern. Med. 113:227-242.

26. Fasano, M. B., and C. E. McCall. 1989. Regulation of interleukin-1 receptor expression on human neutrophils by tumor necrosis factor $\alpha$. Clin. Res. 37:562A. (Abstr.)

27. Dower, S. K., and D. L. Urdal. 1987. The interleukin 1 receptor. Immunol. Today. 8:46-48.

28. Chizzonite, R., T. Truitt, P. L. Kilian, A. S. Stern, P. Nunes, K. P. Parker, K. L. Kaffka, A. O. Chua, D. K. Lugg, and U. Gubler. 1989. Two high-affinity interleukin 1 receptors represent separate gene products. Proc. Natl. Acad. Sci. USA. 86:8029-8033. 
29. Berger, M., R. U. Sorensen, M. F. Tosi, D. G. Dearborn, and G. Doring 1989. Complement receptor expression on neutrophils at an inflammatory site, the Pseudomonas-infected lung in cystic fibrosis. J. Clin. Invest. 84:1302-1313.

30. Zimmerli, W., B. Seligmann, and J. I. Gallin. 1986. Exudation primes human and guinea pig neutrophils for subsequent responsiveness to the chemotactic peptide $N$-formyl-methionyl-leucyl-phenylalanine and increases complement component C3bi receptor expression. J. Clin. Invest. 77:925-933.

31. Buyon, J. P., N. Shadick, R. Berkman, P. Hopkins, J. Dalton, G. Weissmann, R. Winchester, and S. B. Abramson. 1988. Surface expression of Gp 165/ 95, the complement receptor CR3, as a marker of disease activity in systemic lupus erythematosus. Clin. Immunol. Immunopathol. 1:141-9.

32. Bower, W. F., and C. E. McCall. 1990. Differential expression of receptors for tumor necrosis factor (TNF) and complement CR-3 on blood neutrophils of patients with the sepsis syndrome. Clin. Res. 38:351A. (Abstr.)
33. Van Epps, D. E. J. G. Bender, S. J. Simpson, and D. E. Chenoweth. 1990. Relationship of chemotactic receptors for formyl peptide and C5a to CR1, CR3, and Fc receptors on human neutrophils. J. Leukocyte Biol. 47:519-527.

34. Spriggs, M. K., P. J. Lioubin, J. Slack, S. K. Dower, U. Jonas, D. Cosman, J. E. Sims, and J. Bauer. 1990. Induction of an interleukin-1 receptor (IL-1R) on monocytic cells. Evidence that the receptor is not encoded by a T cell-type IL-1R mRNA. J. Biol. Chem. 265:22499-22505.

35. Georgilis, K. C., Schaefer, C. Dinarello, and M. Klempner. 1987. Human recombinant interleukin $1 \beta$ has no effect on intracellular calcium or on functional responses of human neutrophils. J. Immunol. 138:3403-3407.

36. Marucha, P. T., R. A. Zeff, and D. L. Kreutzer. 1990. Cytokine regulation of IL-1 $\beta$ gene expression in the human polymorphonuclear leukocyte. J. Immunol. 145:2932-2937. 